\title{
Refuge
}

Canada's Journal on Refugees

Revue canadienne sur les réfugiés

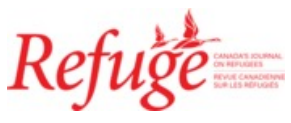

\section{Diasporas Reimagined: Spaces, Practices and Belonging, by Nando Sigona, Alan Gamlen, Guilia Liberatore, and Hélène Neveu Kringelbach (Eds.)}

\section{Elżbieta M. Goździak}

Volume 33, Number 2, 2017

URI: https://id.erudit.org/iderudit/1043067ar

DOI: https://doi.org/10.7202/1043067ar

See table of contents

Publisher(s)

Centre for Refugee Studies, York University

ISSN

0229-5113 (print)

1920-7336 (digital)

Explore this journal

Cite this review

Goździak, E. (2017). Review of [Diasporas Reimagined: Spaces, Practices and Belonging, by Nando Sigona, Alan Gamlen, Guilia Liberatore, and Hélène

Neveu Kringelbach (Eds.)]. Refuge, 33(2), 101-102.

https://doi.org/10.7202/1043067ar 


\title{
Book Reviews
}

\section{Diasporas Reimagined: Spaces, Practices and Belonging}

\author{
$\sim$ \\ Nando Sigona, Alan Gamlen, Guilia Liberatore, and Hélène Neveu Kringelbach, eds. \\ Oxford: Oxford Diasporas Programme, Oxford University, 2015, pp. 231
}

$\mathrm{T}$ he concept of diaspora can be found everywhere: in academic literature, in policy debates at the World Bank, and in works of fiction. There is even a whole journal devoted to diaspora studies. The term and the concept have become household words and have been enlisted in the service of various intellectual, cultural, political, and economic agendas.

It is not a new term. It is a Greek word once reserved to describe Jewish, Greek, and Armenian dispersions or the "classic" diasporas. Today, the term encompasses all immigrant groups. Despite criticisms that the concept may suggest homogeneity and a historically fixed identity, as well as shared values and practices, diasporas are celebrated by academics, community leaders, and policy-makers.

Diasporas Reimagined is an example of such a celebration. The collection, expertly edited by Nando Sigona, Alan Gamlen, Guilia Liberatore, and Hélène Neveu Kringelbach, is designed to showcase the breadth as well as cohesion of research on diasporas linked to the Leverhulme-funded Oxford Diasporas Programme. The publication marks the end of the ODP initiative carried out between 2011 and 2015 and encompassing such wide-ranging studies as diaspora engagement in war-torn societies and in politics and international relations, impact of faith-based community organizations on diaspora inclusion and exclusion in London, African diasporas within Africa, and many others.

The same breadth of topics is included in the book: ways of imagining and conceptualizing diaspora, diasporic belonging and home-making, and the role of social networks and intermediaries in diaspora formation and engagement. The book features contributions from forty-five authors. The style of the contributions adds to the physical and intellectual beauty of the book. Drawing on a range of disciplines, including social anthropology, sociology, human geography, politics, international relations, development studies, and history, the authors depict a world increasingly interconnected through migration. These depictions take the form of photo essays, ethnographic vignettes and case studies, theoretical reflections, and poetic musings.

The book is grouped loosely into four thematic domains: metaphors, concepts, genealogies and images; belonging, imagining and remaking home; spaces, networks, and practices; and governance and mobilisation: old and new actors.

Despite the breadth of information and case study material presented, with very few exceptions-scarcity of employment opportunities for British young men of colour, racist harassment of Muslim immigrants and children of immigrants, to give but a couple of examples-the volume romanticizes the imagined diasporas. I am reminded of a blog post by Toks-Boy Look ma. I am in the Diaspora now!, which opens the book Diasporas by Stéphane Dufoix (2008): "I have been away from Nigeria for 30 years ... All this time I have been 'abroad' studying and working my ass off, sitting in dull offices, with dull people, doing dull things to pay off dull bills when I could have been in the diaspora with nubile virgins with understanding ways. I am so mad."

Indeed, I too have been living outside my homeland for more than thirty years, but never considered myself part of Polonia or the Polish diaspora. I know many Polish refugees and immigrants who do not identify with this imagined community where everyone is supposed to be eating pierogi and dancing the polka. I couldn't dance the polka if my life depended on it!

I hope that as the scholars involved in the Oxford Diasporas Programme chart their future research agendas, they will consider the questions that nobody is asking: Why do we expect immigrants to send remittances home instead of investing in their own or their children's lives in the adopted homeland? Why are diasporas supposed to be responsible for taking care of the issues that the governments of their 
ancestral homelands continue to neglect? And why, for God's sake, are we supposed to focus on our own? Immigrants are as cosmopolitan as the next person. We need to study diasporas' involvement in global issues as well.

In the meantime, however, we can use Diasporas Reimagined as a springboard and inspiration for debating the diversity of immigrant communities and reimagining the migration scholars' and the general public's views of who we, the members-both the enthusiastic and the reluctant ones-of the diaspora really are.

Elżbieta M. Goździak is a research professor at the Institute for the Study of International Migration at Georgetown University. The authormay be contacted at emg27@georgetown.edu.

\section{Elusive Refuge: Chinese Migrants in the Cold War \\ n \\ Laura Madokoro \\ Cambridge, MA: Harvard University Press, 2016, pp. 331}

I $\mathrm{n}$ the aftermath of the Chinese civil war and the 1949 Chinese communist revolution, millions of Chinese from the People's Republic of China crossed over the border into Hong Kong. Once they arrived there, they became caught up in the politics of the Cold War and the contradictions of post-Second World War humanitarianism. Laura Madokoro's timely book on the history of Chinese migrants within this global context provides a well-documented study that will be an important contribution to our understanding of global migration, cold war politics in Asia, humanitarianism, and racial exclusion. The location of Hong Kong as the site of this study provides an especially useful lens for understanding these themes, as this space was characterized by local ambiguities that reflected larger global contradictions and ambivalences towards Asian migrants. Much like a recent book by Rachel Bright on an earlier group of Chinese migrants to the South African gold mines (Chinese Labour in South Africa, 1902-10, Palgrave Macmillan 2013), these accounts of Chinese migrants in white settler colonies (and their post-colonies) throw into relief the boundary struggles over nation, race, and class that their presence provoked. The story Madokoro tells also has resonance for contemporary tensions over the entry of mainland Chinese into Hong Kong since its handing over to the PRC in 1997.

Madokoro situates her work primarily in the literatures on refugees, migrants, and humanitarianism. She outlines the history of the category of "refugee," reminding us of its changing meaning over time as nineteenth-century nation states and national borders created the category of a "stateless person," and after 1951 defined the refugee as a persecuted individual in need of protection. For the migrant Chinese in Cold War Hong Kong, these nuances were critically important. Chinese migrants were viewed (and constructed) by humanitarian organizations as refugees from hardship and persecution, an argument that was embraced by the anti-communist regime in Taiwan but questioned by British colonial officials. The United States and other white settler colonies countered that migrants from the People's Republic of China were "rice refugees" or economic rather than politically persecuted migrants. The specific geopolitical position of Hong Kong made these arguments both specific to the East Asian region and emblematic of global Cold War politics: Hong Kong was a British colony whose governing authorities favoured neutrality in order to maintain relations with the PRC; the colony was historically situated at the edge of mainland China while looking outwards to the West; thus Hong Kong represented a "middle ground" in the competing Cold War claims of the PRC and Taiwan, and this played a key role in these debates.

Not only is this story of migration situated at a critical moment in the history of identity and belonging for East Asia itself, but it is also entangled in the longer historical arc of Chinese exclusion in the white settler colonies. Migrants from Eastern Europe fleeing communism after the war were resettled in the United States and elsewhere in white settler colonies like Canada and Australia, while migrants from Asia generally faced more stringent barriers: "The long history of Chinese exclusion in the West defined the politics around humanitarian assistance and settlement programs for the people from "Red China" (2). European migrants were more likely to be accepted as political refugees, while Asians were not. Madokoro thus spends considerable time outlining the history of Asian exclusion globally and argues that the Chinese migrant experience in Hong Kong must be viewed through this lens.

Madokoro first traces this arc of historical Asian exclusion backward in time from 1950s Hong Kong, then takes us forward into the 1970s with a chapter on refugees from conflict in Indochina. In this case, she argues, the United States and other white settler societies used resettlement of Indochinese refugees to demonstrate their "humanitarian identity" and compassion, while obscuring their histories of 